\title{
高レベル放射性麿棄物処分堨の埋戻しの険討 †
}

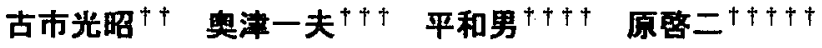

高レベル廃乗物の地層処分では処分地点の選定・調查後の作業段階を建設・操業·埋戻しの3段階に大別することがで

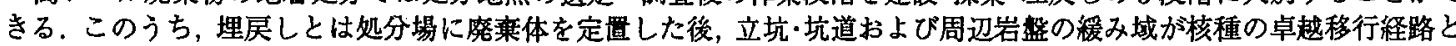
ならないように埋戻し材，プラグおよびグラウトにより適切にシールし，処分場の安全性を長期にわたり確保すること である。

本論文では，処分場の埋戻しの設計方法を提案した。

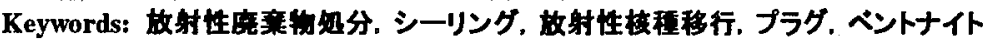

In high level radioactive waste disposal project, the workstages after the selection and the investigation of the dispasal site can be divided into the three phases of construction, operation and sealing. Among these phases, the purpose of sealing is the securing of longterm safety for the repository to prevent the radionuclide migration speed increasing at shaft, tunnel and disturbed zone of host rock, by means of backfill, plugs and grout after waste has been positioned in the repository.

This report proposes a design method of sealing system.

Keywords: radioactive waste disposal, sealing, radionuclide migration, plug, bentonite

\section{1 はじめに}

世界人口は開発途上国を中心に今後さらなる増加が 予想され, 2050 年には 100 億人を超えると言われており， これに伴い電力需要の急增が予測されている，一方，地 球環境問題は深刻化しており，1997 年 12 月の地域温暖 化防止京都会杽では 2008 2012 年の間に二酸化炭素な ど六種類の温室効果ガス排出量を 90 年比で 6\%削減する との目標が日本に課された.このような状況下で原子力 は大量のエネルギーを供給できることおよびクリーン なエネルギーであることから今後のエネルギーの柱と して位置づけられている，しかし，原子力開発における 課題も山積しており，最重要課題の1つとして高レベル 放射性廃棄物(以下高レベル廃弃物)処分が挙げられてい る[1].

高レベル廃妄物の地層処分は処分地点の選定・調查後 の作業段階を建設・操業・埋戻しの3段階に大別すること ができる.このうち, 埋戻しとは立坑・坑道および周辺 岩盤の緩み域が核種の卓越移行経路とならないように 埋戻し材, プラグおよびグラウトを組み合わせたシステ ム（以下シーリングシステム）により適切にシールし， 妈分場の安全性を長期にわたり確保することである.

本報告は，日本の一般的な地質を対象にシーリングシ ステムの設計の基本的な考え方を提案し，モデル地質に 対する具体的なシーリングシステムの仕様を例示する

\footnotetext{
The Study of the Sealing System of High Level Radioactive Waste Repository, by Mitsuaki Furuichi (furuichi@pub.kajima.co.jp), Kazuo Okutsu, Kazuo Taira and Keiji Hara

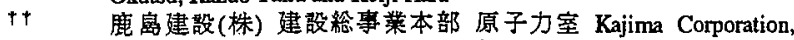
Nuclear Power Dept. $\bar{\top} 107-8502$ 東京都港区赤坂 6-5-30

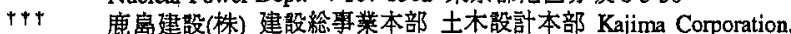
Civil Engineering Design Dept. 广 107-8502 東京都港区赤坂 6-5-30

†ナナ鹿島建设(株) 技術研究所 Kajima Technical Research Institute. 于182-0036 東京都調布市飛田給 2-19-1

$\dagger+t \uparrow \dagger$ 動力炬. 核燃料開発事業団 Power Reactor and Nuclear Fuel Development Corporation. $\bar{T}$ 107-0052 東京都港区赤坂 1-9-13
}

とともに，実験によってベントナイトプラグと周辺岩盤 との間のシール性能を明らかにしたものである。

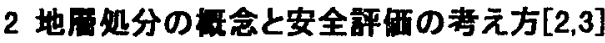

高レベル廃率物の地層処分の概念は，廃裹物を地下数 百メートル以深の安定な地層中に埋設し，核種移行に対 する対策として,人工バリアと天然バリアを組み合せた 多重バリアシステムにより長期の安全性を確保するこ とを基本としている。このため，シーリングシステムに おいては，掘削した空間を適切に埋戻し，多重バリア内 に核種移行速度が周辺の健全岩盤部よりも速くなる部 分を作らないことが求められる。そこで，立坑·坑道を 埋戻した後,この領域には健全岩盤部と同等の難透水性 と核種移行遅延性が求められることになる。

これまでの研究では, 人工バリアおよび周辺岩盤（二 アフィールド）には核種の封じ込め性能が大きく期待で きるとされて扔り，天然バリアの核種封じ込め性能に影 響を与えるような大きな断層・破砕帯に至るまでの天然 バリアの核種移行評価が重要とされている（Fig.1） [2,10,14].この際の評価においては，廃亲体から溶出し た核種が，破砕帯に遭遇したならば直ちに地上へ漏洩す るものとし，それに至るために Fig. 2 に示すように処分 坑道から立坑を通り断層・破砕带に到達寸る経路か, 岩 盤を通過後に到達する経路が考えられる。

シーリングシステムの性能評価においても多重バリ アとしての機能を期待する範囲(以下評価点：Fig.1 にお ける点線の内側部分)の評価が重要である。このため, 本 研究ではこの範囲を取り上げ，核種移行の観点からシー リングシステムの基本要素を検討する。 


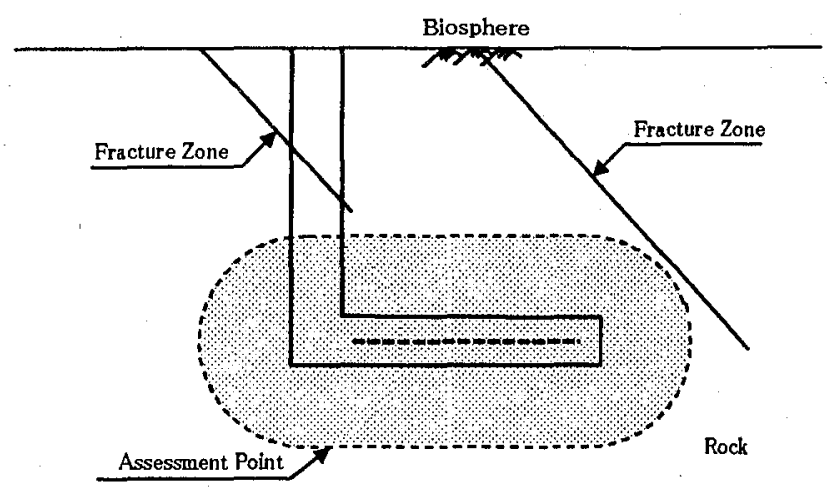

Fig.1 Multibarrier zone

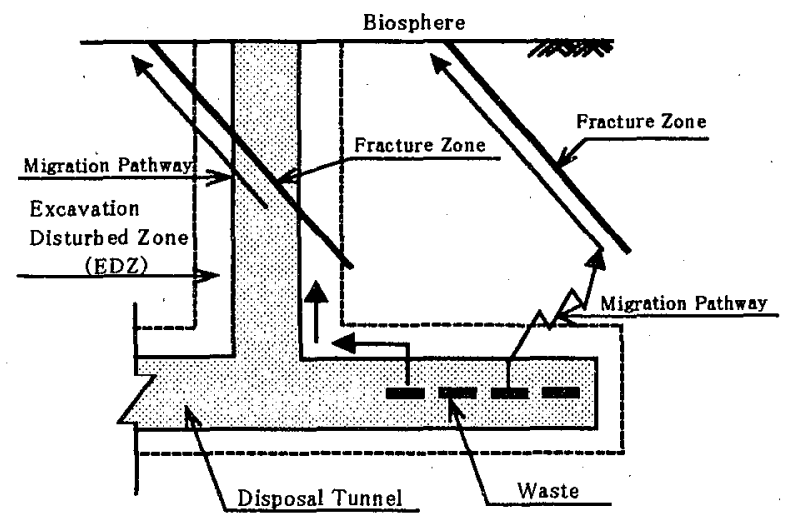

Fig.2 Concept of radionuclide migration pathways

\section{3 シーリング壮様の検討}

\section{1 シーリング方法}

シーリングシステムによって処分場の安全性を確保 するためには，立坑・坑道を通る核種の移行達延性をい かに担保させるかが重要であり，そのためのキーポイン トは岩搵緩み域をいかに処理するかにあると考えられ る.これに対する現実的なシーリング方法としてはこれ までの研究から以下の 2 案が挙げられる.

(1) グラウトによる立坑・坑道周辺岩盤緩み域の透水 性の改善（プラグを用いない）

(2) プラグとグラウトの組合わせによる岩盤緩み域の 地下水流れの遮断

なお，以下においては立坑を例として検討を進めるこ ととする.

(1) グラウトによる立坑周辺岩盤部の透水性の改善（以 下グラウト案)

本案は Fig.3 に示すとおり，岩盤を極力緩ませない掘 削方法を探用し，さらに掘削によって生じた岩盤緩み域
の透水性を粘土系グラウトで改善しようとするものて ある．すなわち，以下の要素技術を組み合わせたシーリ ング方法である.

(1) 高精度掘削による岩盤緩み域発生の抑制

(2) 難透水性／膨潤性材料による立坑の充填

(3) グラウトによる立坑周辺岩盤緩み域の透水性の 改善

(2) プラグによる岩盤緩み域に沿う地下水流れの遮断 (以下プラグ案)

下記に示す 3 つの要素技術を合理的に組み合わせて 核種の移行を遅延しようとするものであり，現時点では 最も信頼性の高いシーリング方法と考えられる。

(1) 難透水性/膨潤性材料による立坑の充填

(2) 難透水性／高膨潤性材料のプラグによる岩盤湲み 域及び埋戻し材と岩盤の境界部の止水

(3) グラウトによるプラグ周辺岩盤緩み域の透水性の 改善

\section{2 シーリングの㭠略止水性能解析}

シーリング効果は峳密には核種移行解析によって確 認すべきであるが，概略的にはシーリング部の透水係数 から評価できる。この評価法をここでは概略評価と呼ぶ ことにする.

立坑のシーリングは掘削による楥み域を含んだ立坑 部分が健全母岩と同オーダーの難透水性を有すること を目標性能と考え，掘削前の健全岩盤の透水係数と掘削 後のシーリング部の透水係数を比較することでシーリ ング効果を評価する.

ここでは目安として廃㲤体から評価点までの距離 $(L)$ を $100 \mathrm{~m}$ と設定して，グラウト案およびプラグ案のシー リング性能を評価することとする。

(1) 解析用物性値

解析上重要なパラメータとなる岩盤部透水係数は日 本の標準的な岩盤を想定し，10-8 $\mathrm{m} / \mathrm{sec}$ オーダーとした [2]. また，掘削による岩盤緩み域は健全な岩盤より透水 係数が 2 オーダー大きくなり，さらにグラウトで改良す ることにより透水係数が 1 オーダー小さくなるものと 仮定した[4]. 岩盤緩み域の範囲は既往研究 $[5,6]$ より立坑 壁面から $1 \mathrm{~m}$ 深さとした．また，埋戻し材の透水係数は $k=10^{-9} \mathrm{~m} / \mathrm{sec}$ と設定した[3].

なお，Fig.4において A 部はプラグ掘削による応力集 中が小さいため，岩盤緩み域がほとんど発生しないとの 報告[7]がなされており，透水倸数は健全岩然と同等とし $\tau k=10^{-8} \mathrm{~m} / \mathrm{sec}$ とした. また, ベントナイトプラグの透水 係数は $k=10^{-10} \mathrm{~m} / \mathrm{sec}$ とした[3]. 


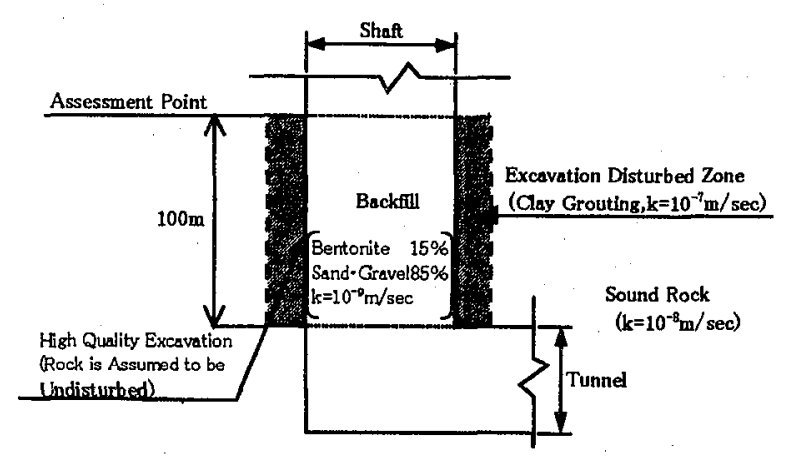

Fig.3 Option of lower shaft sealing(Grouting)

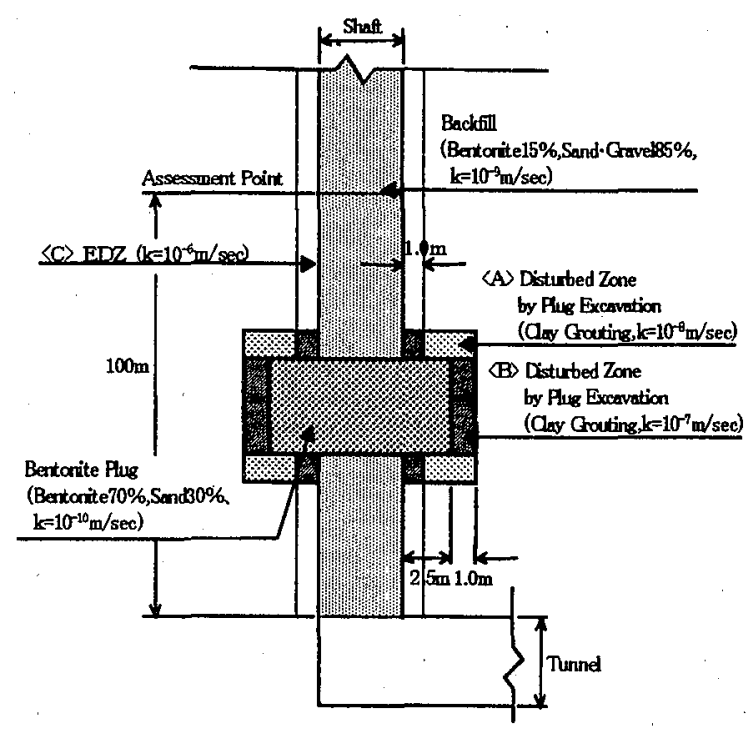

Fig.4 Option of lower shaft sealing(Plug)

（2）シーリング部の平均透水係数

ブラグ設置部周辺の形状寸法および透水係数の分布を Fig.5に示す.プラグおよび緩み域を含む立坑部分の軸方 向の平均透水係数は次式で定義できる.

$$
\bar{K}=\frac{A_{b} K_{b}+A_{d} \overline{K_{d}}}{A_{b}+A_{d}}
$$

ここに, $\bar{K}$ : 平均透水係数

$K_{b} \quad$ : 立坑埋戻し部の透水係数 $\left(10^{-9} \mathrm{~m} / \mathrm{sec}\right)$

$A_{b} \quad$ : 立坑埋戻し部の面積 $\left(3.25^{2} \times \pi \mathrm{m}^{2}\right)$

$\overline{K d}$ : 緩み域の平均透水係数

$A_{d}$ : 楥み域の断面積 $\left(\left(4.25^{2}-3.25^{2}\right) \times \pi \mathrm{m}^{2}\right)$

また，立坑周辺の地下水は，以下の各部 (Fig.4における

$\langle\mathrm{A}\rangle,\langle\mathrm{B}\rangle,\langle\mathrm{C}\rangle)$ を通るものと仮定する.

〈A〉：プラグ掘削による岩盤縓み域（延長 $\ell p d 1$, Fig.

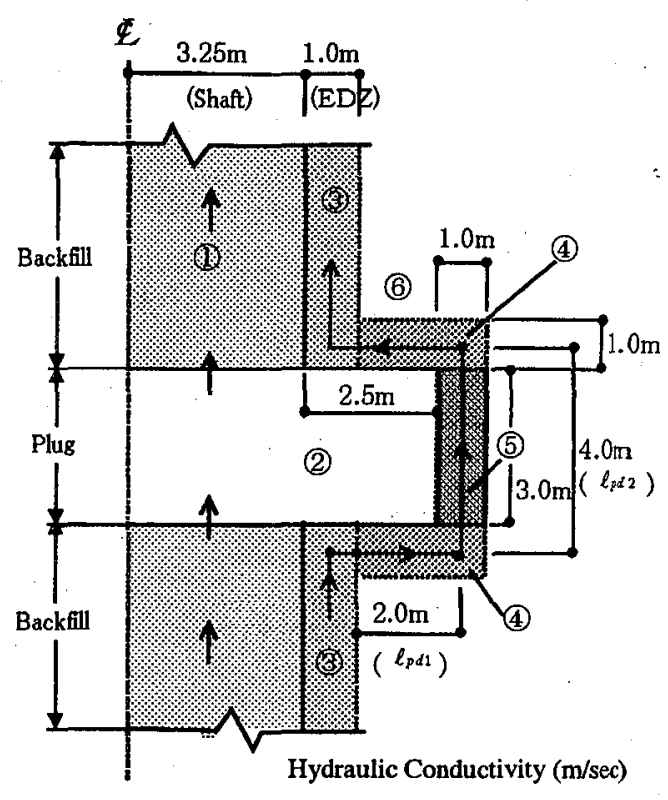

(1) Backfill

$: K_{b} \quad=10^{-9}$

(2) Plug

$: K_{p} \quad=10^{-10}$

(3) EDZ by Shaft Excavation

$\langle\mathrm{C}\rangle: K_{d} \quad=10^{-6}$

(4) Disturbed Zone by Plug Excavation $\langle\mathrm{A}\rangle: K p d 1=10^{-8}$ (Rock is Assumed to be Undisturbed)

(5) Disturbed Zone by Plug Excavation $\langle\mathrm{B}\rangle: K p d 2=10^{-7}$ (Hydraulic Conductivity is improved by Clay Grouting)

(6) Sound Rock $: K_{r} \quad=10^{-8}$

Fig. 5 Section of shaft sealing

5 で(4)に相当)

（楥みが少なく透水性がほとんど変化しない 部分)

〈B〉：プラグ掘削による岩盤楥み域（延長 $\ell p d 2, F i g .5$ で(5)に相当)

(グラウトにより透水性を母岩より1オーダ 一大きい程度まで改善できる部分)

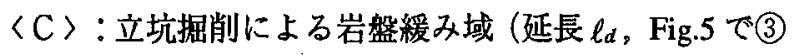
に相当)

楥み域の平均透水係数 $\left(\overline{K_{d}}\right)$ は(2)式で表わす．(プラ グ部は搪幅されており，(2)式は厳密には正確でないがシ ーリング効果を透水係数のオーダーで概略評価するこ とが目的であるので便宜的に用いた。）

$$
\frac{L}{\overline{K_{d}}}=\frac{\ell_{d}}{K_{d}}+\frac{\ell_{p d 1}}{K_{p d 1}}+\frac{\ell_{p d 2}}{K_{p d 2}}
$$

ここに, $L \quad:$ 水みち延長 
$\ell d \quad$ : 立坑掘削による緩み域の長さ

$\ell_{p d 1}$ : プラグ掘削による緩み域の長さ

(Fig.5で(4)に相当)

$\ell_{p d 2}$ : プラグ掘削による緩み域の長さ

(Fig.5 で(5)に相当)

$K d ：$ 立坑掘削による緩み域の透水係数

$K_{p d 1}$ : プラグ掘削による緩み域の透水係数（透 水性が活とんど変化しない部分)

$K_{p d 2}$ :プラグ掘削による緩み域の透水係数（透 水性が変化するがグラウトによって母 岩より 1 オーダー大きい程度まで改善 できる部分)

Table 1 は式(1)及び(2)を用いて平均透水係数を求めた 結果である.No.0は立坑部に埋戻しのみを実施した場合 である. No.a は立坑下部全域の立坑周辺岩㭰の緩みをグ ラウトで改良する案（グラウト案）である、No.b-1〜 No.b-5 はプラグを設置し，さらにプラグ周辺の岩盤緩み 域をグラウトで改良する案（プラグ案）である。これに よると，埋戻しのみを実施する場合，立坑とその周辺の 岩然緩み域の平均透水係数は $4.2 \times 10^{-7} \mathrm{~m} / \mathrm{sec}$ である。 れに対しグラウト案の場合，平均透水係数は $4.2 \times 10^{-8}$ $\mathrm{m} / \mathrm{sec}$ となり，埋戻しのみの場合（No.0）に比べて $1 / 10$ まで透水性が改善される。一方，プラグ案についてはプ ラグを 1 個設置することにより，平均透水係数は $7.9 \times$ $10^{-8} \mathrm{~m} / \mathrm{sec}$ となり埋戻しのみの場合 (No.0)に比べて約 $1 / 5$ まで透水性が改善される。すなわち，両案とも健全母岩 と同オーダーの透水性まで改善されることがわかる。

グラウト案とプラグ案を比較すると，粘土グラウト技 術がまだ開発途中であることからグラウト案について は，グラウトの止水性能において不安が残る。一方，プ ラグ案については粘土グラウトを用いるがその範囲は プラグ周囲のみに限定され，岩盤条件によってはプラグ の個数を増やすことも可能である。また，プラグ性能に ついては実験的に確認されており[9], 原位置においても プラグ性能を実証すべく動力炬・核然料開発事業団と $\mathrm{AECL}$ カナナ゙原子力公社)の共同研究として AECL の地 下研究施設で実験の準備が進められている[15].

これらを勘案して，ここでは実証が進んでいるプラグ 案に対して核種移行の観点からシーリング性能の評価 を行うこととする。

\section{3 シーリングの校種封じ込め性能解析}

3.2 において立坑下部にプラダを 1 個設置し，プラ グ設置のための掘削部分をグラウトで改良することで 健全岩盤と同オーダーの難透水性を確保できることを
Table 1 Average hydraulic conductivities of shaft components

\begin{tabular}{|c|r|r|r|r|r|r|r|r|}
\hline No. & $\begin{array}{c}\text { Num } \\
\text { ber } \\
\text { of } \\
\text { Plug }\end{array}$ & $\begin{array}{c}\ell_{d} \\
(\mathrm{~m})\end{array}$ & $\begin{array}{c}\ell_{\alpha+1} \\
(\mathrm{~m})\end{array}$ & $\begin{array}{c}\ell_{p d 2} \\
(\mathrm{~m})\end{array}$ & $\begin{array}{c}L \\
(\mathrm{~m})\end{array}$ & $\begin{array}{c}\mathrm{EDZ} \\
\text { Average } \\
\bar{K} d \\
(\mathrm{~m} / \mathrm{sec})\end{array}$ & $\begin{array}{c}\text { Average } \\
\text { Shaft } \\
(\mathrm{m} / \mathrm{sec})\end{array}$ & $\begin{array}{c}\text { fof } \\
\text { EDZ+ } \\
\text { Shaft } \\
\bar{K} \\
(\mathrm{~m} / \mathrm{sec})\end{array}$ \\
\hline 0 & 0 & 100 & 0 & 0 & 100 & $1.0 \mathrm{E}-06$ & $1.0 \mathrm{E}-09$ & $4.2 \mathrm{E}-07$ \\
\hline a & 0 & 100 & 0 & 0 & 100 & $1.0 \mathrm{E}-07$ & $1.0 \mathrm{E}-09$ & $4.2 \mathrm{E}-08$ \\
\hline $\mathrm{b}-1$ & 1 & 96 & 4 & 4 & 104 & $1.9 \mathrm{E}-07$ & $1.0 \mathrm{E}-09$ & $7.9 \mathrm{E}-08$ \\
\hline $\mathrm{b}-2$ & 2 & 92 & 8 & 8 & 108 & $1.1 \mathrm{E}-07$ & $1.0 \mathrm{E}-09$ & $4.6 \mathrm{E}-08$ \\
\hline $\mathrm{b}-3$ & 3 & 88 & 12 & 12 & 112 & $8.0 \mathrm{E}-08$ & $1.0 \mathrm{E}-09$ & $3.3 \mathrm{E}-08$ \\
\hline $\mathrm{b}-4$ & 4 & 84 & 16 & 16 & 116 & $6.3 \mathrm{E}-08$ & $1.0 \mathrm{E}-09$ & $2.6 \mathrm{E}-08$ \\
\hline $\mathrm{b}-5$ & 5 & 80 & 20 & 20 & 120 & $5.3 \mathrm{E}-08$ & $1.0 \mathrm{E}-09$ & $2.2 \mathrm{E}-08$ \\
\hline $\mathrm{c}$ & & & & & 100 & $1.0 \mathrm{E}-08$ & $1.0 \mathrm{E}-08$ & $1.0 \mathrm{E}-08$ \\
\hline
\end{tabular}

No.0 : Plug is Not Considered,Grout is Not Considered

No.a : Plug is Not Considered,Grout is Considered

No.b-i : Plug is Considered,Grout is Not Considered

No.c : Sound Rock

確認した.

ここでは，さらに核種の移行解析によって評価点での核 種濃度を健全岩盤の場合と比較することによってシー リンダシステムの有効性を確認することとする。

(1) 解析手法[8]

解析は有限要素法による 3 次元・水理・核種移行解析コ ード FEMCOUP/MIGRATIONを用いて実施した。以下に その概要を示す。

$$
\begin{aligned}
& S \frac{\bar{\partial} H}{\partial t}=\nabla(k \cdot \nabla) H+Q \\
& U=-(k \cdot \nabla) H / \theta
\end{aligned}
$$

$$
\begin{aligned}
\text { ここに, } S & \text { : 眝留係数 } \\
H & \text { : 全水頭 } \\
k & : \text { 透水係数 } \\
Q & : \text { 湧水および給水割合 } \\
U & : \text { 地下水流速 } \\
\theta & : \text { 間隙率 }
\end{aligned}
$$

式(3)により水頭 $H$ を求め，式(4)により地下水流速が 求められる。

一方，核種移行の支配方程式は，移流拡散，核種自身 の崩壤，親核種からの崩壤，浸出率を考慮に入れて，式 (4)で得られる地下水流速を用いて，次式で表される。

$$
\theta R_{m} \frac{\dot{o} C_{m}}{\partial t}+\theta(U \cdot \nabla) C_{m}=\theta \nabla \cdot\left(D_{L} \nabla C_{m}\right)
$$




$$
-\theta R_{m} \lambda_{m} C_{m}+F_{m}
$$

$$
\begin{aligned}
& R_{m}=1+K_{d m} \rho(1-\theta) / \theta \\
& D_{L}=\alpha_{L} \cdot V_{L}+D
\end{aligned}
$$

\section{ここに, $R_{m}$ : 第 $\mathrm{m}$ 番目の核種の遅延係数}

$K_{d m}$ : 第m番目の核種の分配係数

$C_{m} \quad$ : 第 $\mathrm{m}$ 番目の核種濃度

$D_{L}$ : 分散係数

$\alpha_{L}$ : 分散長(漏洩点と評価点との距離の $10 \%$ を想定)

$V_{d}:$ ダルシー流速

$D$ : 拡散係数

$\lambda_{m}$ : 第 $\mathrm{m}$ 番目の核種の崩壊定数

$\left[\mathrm{L}^{2} / \mathrm{t}\right]$

$F_{m}:$ 核種放出率

$m$ : 核種番号 $(m=1,2,3,4,5)$

$[1 / \mathrm{t}]$

$\left[\mathrm{M} / \mathrm{L}^{3} \mathrm{t}\right]$

$\rho \quad:$ 真の密度

なおここでの $F_{m}:$ 核種放出率とは，いわゆるガラス 固化体の溶解速度や核種の溶解度によって規定される ものではなく, 解析上の仮定として, 人工バリアから溶 出した核種が核種漏洩点(Fig.6 参照)において立坑へ流 出する割合を想定したものである。

以上の水理に関する支配方程式と核種移行に関する 支配方程式を有限要素法を用いて解析しはたたし, 本報告 では親核種からの崩壊は考慮しない), 地下水流速と核種 濃度分布を求める。

(2) 解析条件

a) 解析に用いた核種

地層処分システムの性能評価において重要とされて いる核種のうち分配係数が小さく，比較的半減期の長い 代表的な核種である Tc-99(半減期 :21.3 万年) と Np-237 (半減期 :214万年) を用いる。

b) 解析用物性值

Table 2 に解析に使用した物性值を示す[2,3].

c) 解析モデル

解析上の核種漏洩点は Fig.6, Fig.7に示すように立坑 下部とし，立坑上部に向かって等分布で一定皓の核種を 对象核種の半減期まで継続的に浸出させた。

モデルは軸対称を仮定し，解析領域の範囲は軸方向に は核種漏洩点加ら評価点まで $\left(\mathrm{L}_{1}=100 \mathrm{~m}\right)$ ，半径方向には $\mathrm{L}_{2}=50 \mathrm{~m}$ （寸法の比は $2: 1$ ）とした[8].

(3) 解析結果

\begin{tabular}{|c|c|c|c|c|c|c|}
\hline & \multirow{2}{*}{\begin{tabular}{|c|} 
Hydraulic \\
Conductiv- \\
ity \\
$(\mathrm{m} / \mathrm{sec})$
\end{tabular}} & \multirow{2}{*}{$\begin{array}{c}\text { Bulk } \\
\text { Density } \\
\left(t / \mathrm{m}^{3}\right)\end{array}$} & \multirow[t]{2}{*}{ Porosity } & \multicolumn{2}{|c|}{$\begin{array}{c}\text { Distribution } \\
\text { Coefficient } \\
\left(\mathrm{m}^{3} / \mathrm{kg}\right)\end{array}$} & \multirow{2}{*}{$\begin{array}{l}\text { Diffusion } \\
\text { Coefficient } \\
\left(\mathrm{m}^{2} / \mathrm{sec}\right)\end{array}$} \\
\hline & & & & $\mathrm{Np}-237$ & Tc-99 & \\
\hline $\begin{array}{c}\text { Rock } \\
\text { (Undisturb- } \\
\text { ed) }\end{array}$ & $10^{-8}$ & 2.7 & 0.01 & 0.001 & 0.0001 & $5 \times 10^{-10}$ \\
\hline $\begin{array}{c}\text { Rock } \\
\text { (Disturbed) }\end{array}$ & $10^{-6}$ & 2.7 & 0.05 & 0.001 & 0.0001 & $5 \times 10^{-10}$ \\
\hline $\begin{array}{c}\text { Rock } \\
\text { (With Grout A) }\end{array}$ & $10^{-8}$ & 2.7 & 0.05 & 0.001 & 0.0001 & $5 \times 10^{-11}$ \\
\hline $\begin{array}{c}\text { Rock } \\
\text { (With Grout B) }\end{array}$ & $10^{-7}$ & 2.7 & 0.05 & 0.001 & 0.0001 & $5 \times 10^{-10}$ \\
\hline Plug & $10^{-10}$ & 1.8 & 0.4 & 0.1 & 0.001 & $5 \times 10^{-11}$ \\
\hline Backfill & $10^{-9}$ & 1.8 & 0.3 & 0.1 & 0.001 & $5 \times 10^{-11}$ \\
\hline
\end{tabular}

解析結果を Fig.8, Fig.9に示す。核種濃度は評価点にお
Table2 Properties of materials

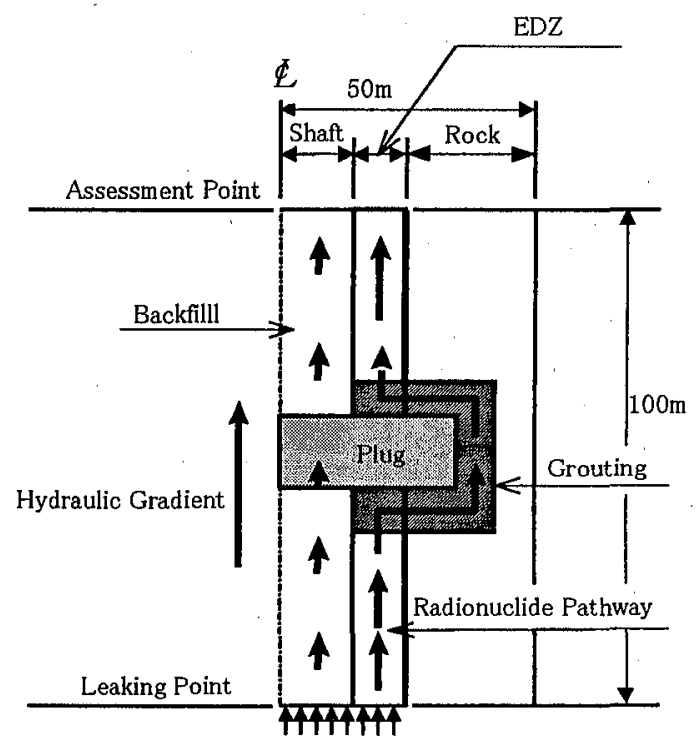

Fig.6 Schematic picture of radionuclide pathway

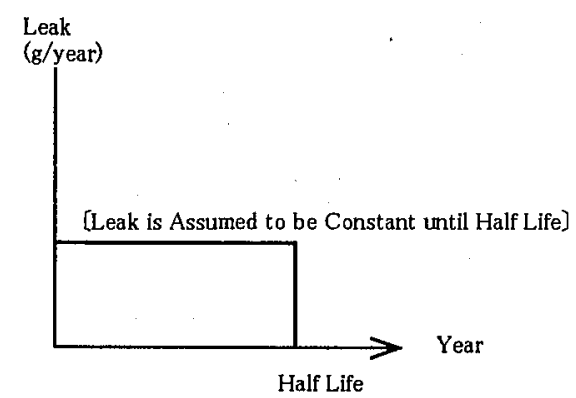

Fig.7 Leak of radionuclide from assessment point 


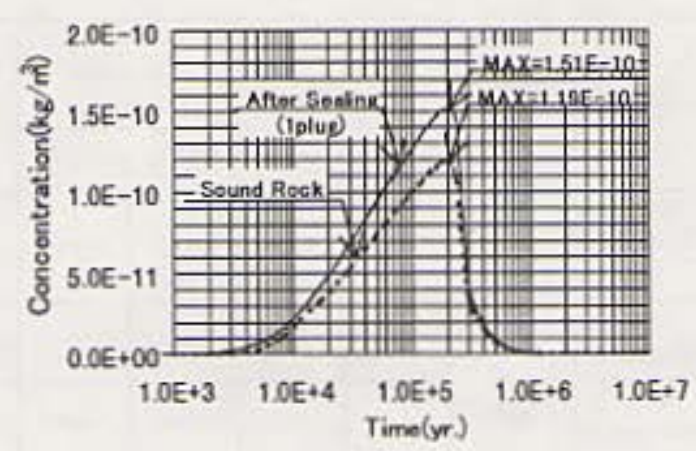

Fig.8 Evaluation of plug effect as to $\mathrm{Tc}-99$ migration

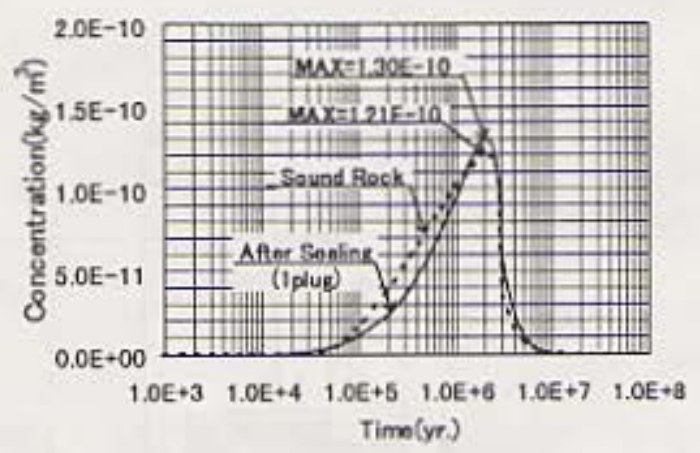

Fig.9 Evaluation of plug effect as to $\mathrm{Np}-237$ migration

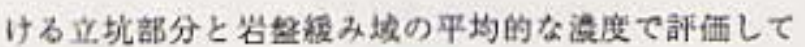
wる.

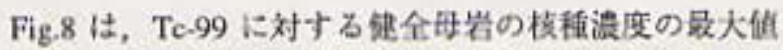
が $1.19 \times 10^{-10} \mathrm{~kg} / \mathrm{m}^{3}$, ブラグ案シーリンク部の核種潘度の 最大稘が $1.51 \times 10^{-10} \mathrm{~kg} / \mathrm{m}^{3}$ を示しており，Fig.9は Np-237 に対して的者が $1.21 \times 10^{\mathrm{ta}} \mathrm{kg} / \mathrm{m}^{3}$, 復者加 $1.30 \times 10^{70} \mathrm{~kg} / \mathrm{m}^{3}$ を示している、すなわち、評価点での校稙港度の最大值

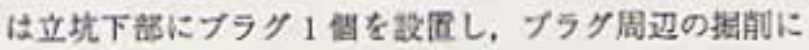
よる炭盤悢み域にリラカトを泩入することで，Te-99，

Np-237 共に健全岩盤と同オーダーに抑えられることが

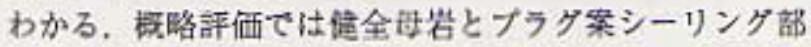
の透水係数の比仙 $K r: \bar{K}=1: 8$ でったのに対し，核

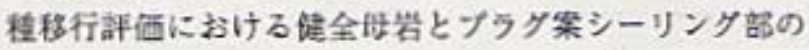

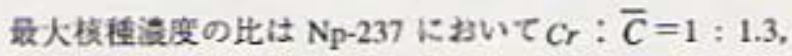

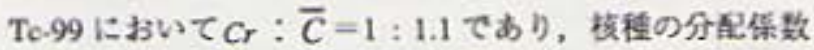

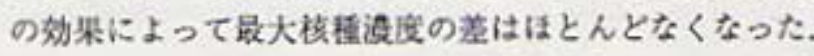

以上より，提案したブラク案て目標とするシーリンタ 性能が磪保できることが碓䛱できた。 また，立坑部の地

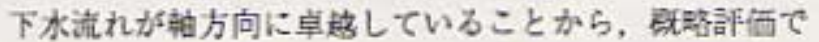

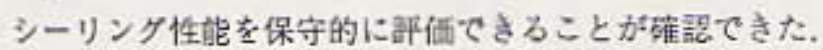

\section{4 ブラグと周辺岩盤間のシール性能の評価}

フラクと周边岩盤間のシール性能はシーリングによ

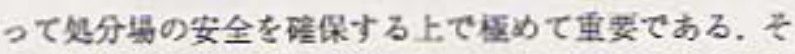

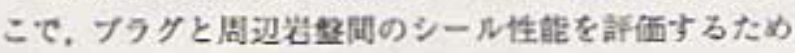
に以下の空内透水实梌を实䅦した[9].

\section{1 鼓歌体}

フララクの椎工力法として，圧梢ブロックを坑道内に稍 み重かることを想定し，Fig.10に示なように， 7 つに分 㲅した砂・ベントナイト泥合土の压粮フロック策合体圶

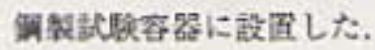

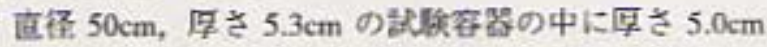

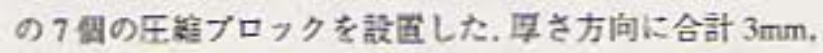

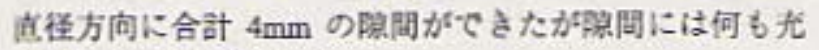
填せずに試駼に供した。

\section{2 使用材料}

使用材料は，山形景産 $\mathrm{Na}$ ベントナイトとケイ矽 (3 号と 5 号の 1: 1 混合)であり、ベントナイトとケイ矽を

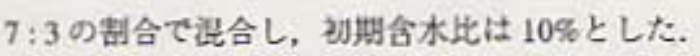

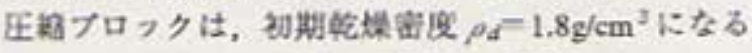
上うに, $10 \mathrm{MPa}$ 程度の压力で压略しで作した。

\section{3 鼓㡎方法}

試験体（压縮フロック柴合你）に対し，0.01MPaの通

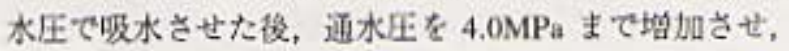

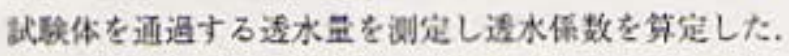

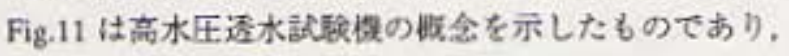

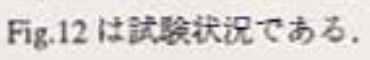

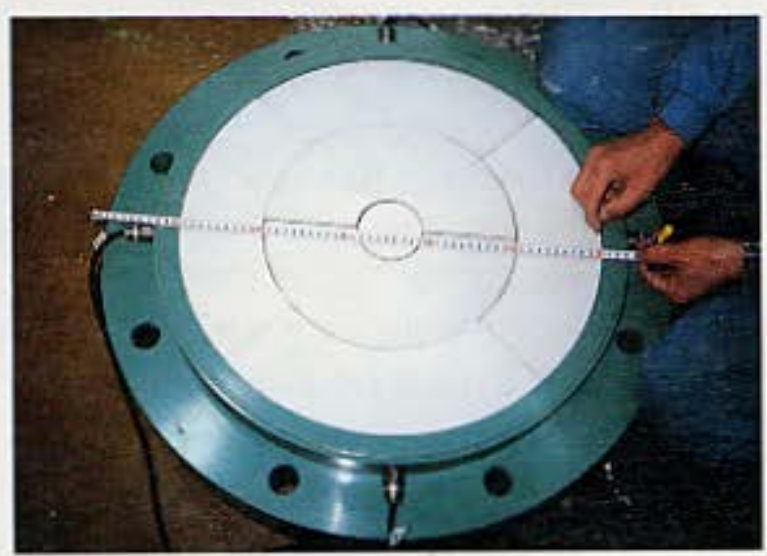

Fig.10 Compacted bentonite block 


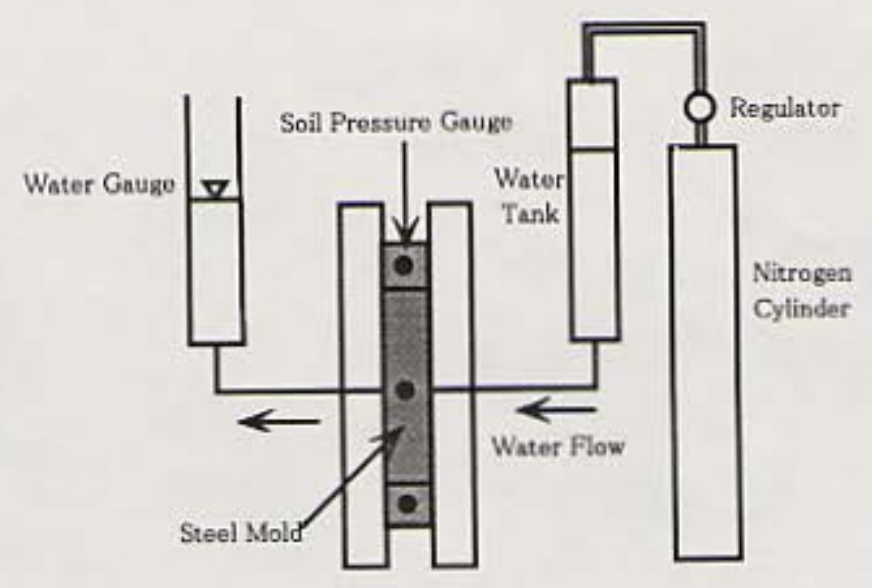

Fig.11 Schematic picture of high preseure hydraulic conductivity test

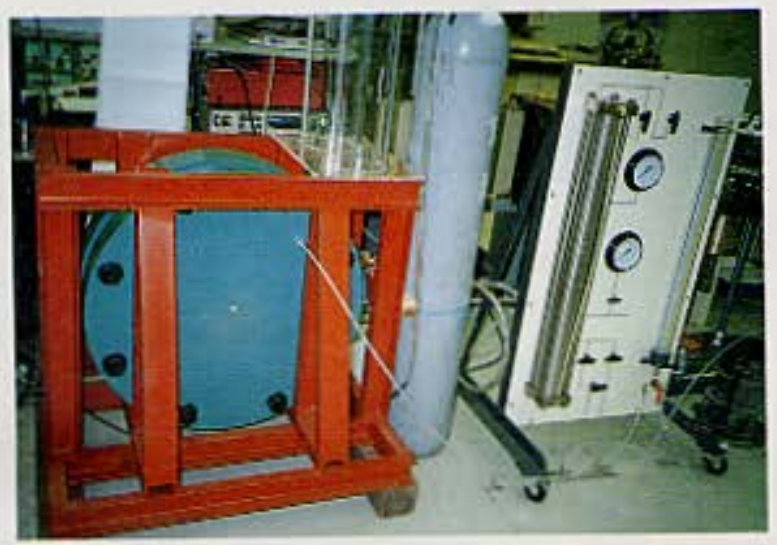

Fig.12 Hydraulio conduotivity test

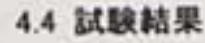

Fig.13 は，通水压と透水諙数の格时交化を示したるの

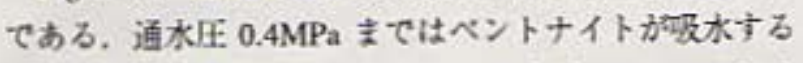
たけで非水見られなかったが，道办开 $0.8 \mathrm{Mpa}$ で初か

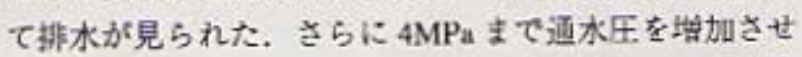
ても通水最はほは一定て, 最数的に道水压 $4 \mathrm{MPa}$ ての透

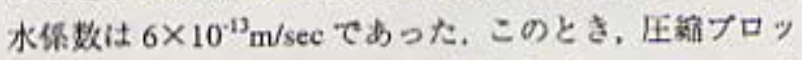

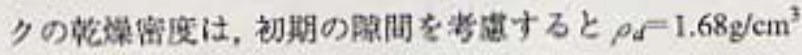
でった.

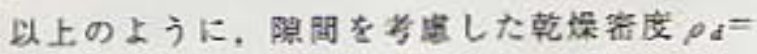
$1.68 \mathrm{~g} / \mathrm{cm}^{3}$ の砂・ヘントナイト摆合土の压粮プロフク柴合 华の透水你数仕 $10^{-12} \mathrm{~m} / \mathrm{sec}$ 程度て，十分去进断在を有し

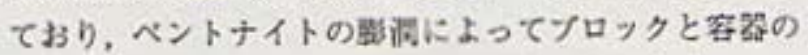
䁬間は十分にシールされているものと䛨㑋できた。

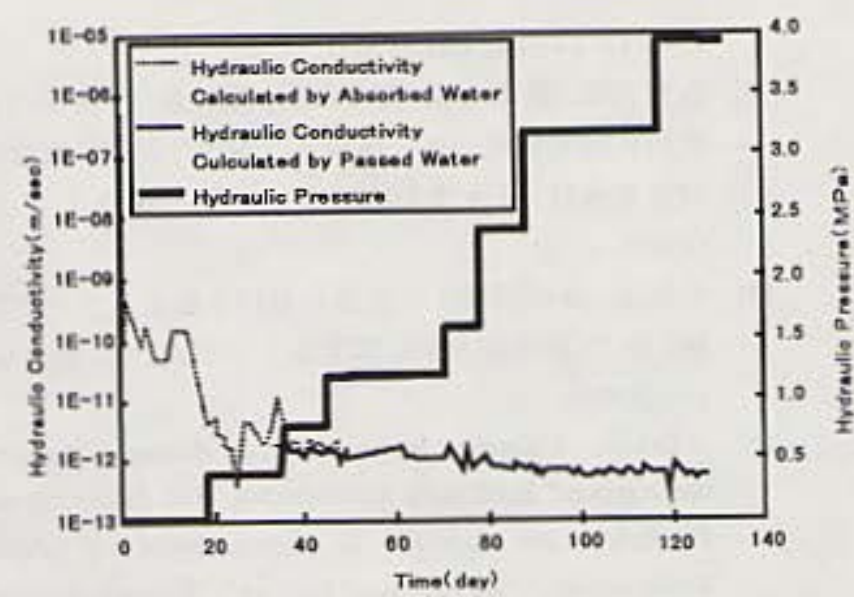

Fig. 13 Change of hydraulic conductivity

\section{5 鼓能}

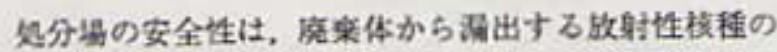
人体への影㬐を十分低いレベルに抑えることで磪保さ れる、立坑は核䄸移行経路になりやすいと考えられるが， 立坑下部にブラグを設需することにより，周辺键全岩桖 と同等の核理移行逢延珄が得られることをモデル地留

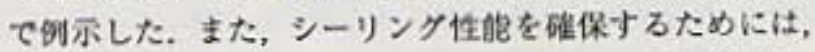

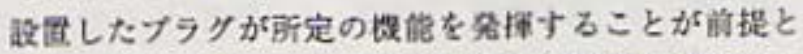

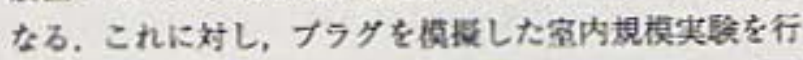

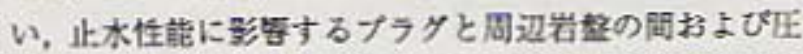
路ペントナイトプロンク閒のシール性施が碓保できる ことを实段によって磪記した。

今後界サイトを対名に処分場のシーリンクを設計す ॐ上Cは,

\section{「地繁の不均留」}

「断展の存住」

「連分システムの長期的安定性」

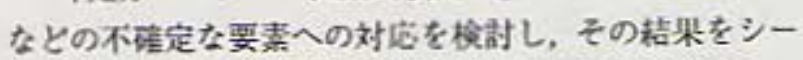
リンタシスティに反映していくことが重要と考えらる.

\section{米辞}

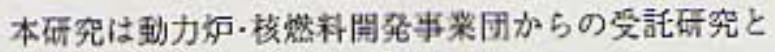

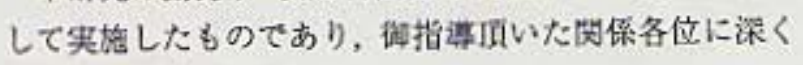
龂諸与る次第である.

\section{为考女郣}

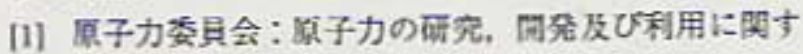
ろ長期計百 (1994).

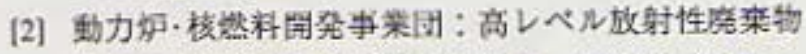

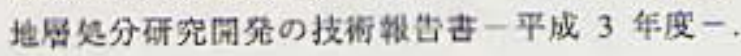


PNC TN 1410 92-081 (1992).

[3] 古市光昭, 奥津一夫, 田中後行, 棚井憲治: 高レベル 放射性廃章物処分場の埋戻し (シーリング) 概念に 関する検討. 土木学会詥文集 VII, No.594/VII-7, 21-33 (1998).

[4] 杉田裕, 藤田朝雄：原位置における粘土グラウト試 験. 第 27 回岩盤力学に関するシンポジウム. pp.276280 (1996).

[5] V.Bräuer, J.Sönnke: Investigation of damaged zone in underground hard rock laboratories. 3rd International Workshop on Design \& Construction of Final Repositories "Plugging and Sealing", Toroyes, France, October 18-20, 1995 (1995).

[6] 松井裕哉, 杉原弘造, 佐藤稳紀, 吉岡尚也: 堆皘岩地 山における立坑周りの力学的・水理学的な特性変化. PNC TR/GE 92-06 (1992).

[7] AECL: Tunnel sealing expriment at URL, AECL Technical Report (in press).

[8] A.Saotome, et al: Study of the performance of sealing systems for access shafts in a high-level waste repository. Scientific Basis for Nuclear Waste Management XVI (Mater. Res. Soc. Symp. Proc. Vol.294) (Interrante, C.G. and Pabalan, R.T. ed.), Pittsburgh, Pennsylvania, U.S.A., November 30-December 4, 1992, pp.475-480 (1993).

[9] 营野媇, 棚井憲治, 平和男, 末吉隆信:圧縮ベントナ イトブロック集合体の透水性.日本原子力会 1997 秋 の大会, 沖縄, 10 月 14 17 日, pp.2009-2010 (1997).

[10] SKB: Final storage of spent nuclear fuel, KBS3 (1983).

[11] SKB: Final disposal of spent nuclear fuel, Importance of the bedrock for safety, SKB Technical Report 92-20 (SKB91) (1992).

[12] AECL: Environmental impact statement on the concept for disposal of canada's nuclear fuel waste, AECL-10700, COG-93-1 (1994).

[13] NAGRA: Project Gewähr, NGB85-09 (1985).

[14] NAGRA: Safety assessment report (Kristallin-I), Nagra Technical Report 93-22 (1994).

[15] 動力炬・核燃料開発事業団 : 地層処分研究開発の現 㫛(平成 8 年度). PNC TN 1410 96-071 (1996). 